\title{
Rancang Bangun Sistem Keamanan Ganda Interaktif Kendaraan Bermotor Roda Dua Berbasis RFID (Radio Frequency Identification)
}

\author{
Eko Susanto ${ }^{1}$, Herlinawati $^{2}$, Umi Murdika $^{3}$ \\ Jurusan Teknik Elektro Universitas Lampung, Bandar Lampung \\ Jl. Prof. Sumantri Bojonegoro no.1 lampung 35145 \\ ${ }^{1}$ oekoko. susanto@gmail.com \\ ${ }^{2}$ herlinawati.rusydi@yahoo.com \\ ${ }^{3}$ umimurdika@yahoo.com
}

Intisari - Rancang bangun sistem keamanan ganda interaktif kendaraan bermotor roda dua berbasis RFID dilengkapi fitur keamanan darurat dengan akurasi dan presisi yang menunjang terwujudnya sistem keamanan interaktif. Metode penelitian yang dilakukan berupa perancangan dan pengujian (pengujian subsistem dan pengujian sistem keseluruhan). Data penelitian berupa data hasil pengujian subsistem identifikasi RFID, deteksi GPS, aksi Rele, dan komunikasi GSM. Sistem keamanan ganda kendaraan bermotor roda dua berbasis RFID yang dihasilkan sesuai dengan ketentuan fungsi sistem yang interaktif. Sistem memiliki rata-rata waktu tunda kerja sebesar 5.6 detik untuk awal sistem dihidupkan dan 1.6 detik untuk aksi terhadap kondisi masukan. Waktu tunda terjadi akibat penggunaan sepasang pin komunikasi serial mikrokontroler Arduino Uno R3 yang harus memenuhi kebutuhan proses komunikasi serial sistem untuk identifikasi RFID, deteksi GPS, dan komunikasi GSM dalam satu waktu.

Kata kunci - Sistem keamanan, RFID, GPS, GSM

Abstract - The interactive double security system of two-wheeled motor vehicles design based on RFID equipped with an emergency security features with accuracy and precision that support the realization of an interactive security system. The method of research was done by designing and testing (subsystem testing and overall system testing). Research data was result data testing of RFID identification subsystem, GPS detection, the relay action, and GSM communication. The interactive double security system of two-wheeled motor vehicles design based on RFID that created was according to the provisions of interactive system functions. The system had an average of delay time 5.6 seconds for system starting and 1.6 seconds for the action of input conditions. Delay time caused by the use of only a pair of Arduino Uno R3 Microcontroller serial communication pin which is should meet the needs of serial communication systems for RFID identification, GPS detection, and GSM communication at one time.

Keywords - Security System, RFID, GPS, GSM.

\section{PENDAHULUAN}

Laju pertumbuhan jumlah kendaraan bermotor roda dua diiringi dengan bertambahnya tindak kriminalitas pencurian. Masyarakat yang menjadi korban pencurian tidak hanya kehilangan materi tetapi juga kehilangan nyawa. Sistem keamanan yang telah dikembangkan pada kendaraan bermotor roda dua belum cukup untuk mengurangi tindak pencurian.
Berkaitan dengan hal ini, perlu diciptakan sebuah sistem keamanan bagi kendaraan bermotor roda dua. Salah satunya dengan memanfaatkan Radio Frequency Identification (RFID) untuk menciptakan sistem kendali identifikasi terhadap suatu benda dengan memanfaatkan gelombang radio pada frekuensi tertentu.

Identifikasi dilakukan dengan memasangkan RFID tag atau transponder sebagai kunci kendaraan kemudian dideteksi oleh reader. RFID dapat mendukung 
terciptanya sistem keamanan berdasarkan kendali identifikasi yang dihasilkan.

Rancangan sistem keamanan ini menggunakan Arduino sebagai pengendali utama, dimana terdapat fitur short message alert yang mampu memberikan informasi berupa peringatan dan posisi kendaraan bermotor roda dua berada, sehingga diharapkan mampu menjadi inovasi sistem keamanan kendaraan bermotor roda dua yang telah diterapkan sebelumnya untuk mewujudkan sistem keamanan interaktif.

\section{TINJAUAN PUSTAKA}

\section{A. RFID (Radio Frequency Identification)}

Penemuan alat pengintai oleh seorang ilmuwan Rusia bernama Leon Theremin pada tahun 1946 merupakan pelopor yang mengawali terciptanya teknologi RFID (Radio Frequency Identification). Alat pengintai yang disebut "thing" dapat memancarkan kembali gelombang radio dengan informasi suara. RFID modern diawali dengan paten yang dimiliki oleh Mario Cardullo pada tahun 1973, di mana terdapat transponder pasif yang memiliki memori [1].

RFID adalah suatu metode untuk melakukan identifikasi manusia, hewan, atau objek secara otomatis berdasarkan gelombang radio. RFID biasanya menggunakan transmisi gelombang radio dengan frekuensi $125 \mathrm{kHz}$, 13.65 MHz, atau 800-900 MHz. RFID memiliki standar frekuensi yakni sebesar 125 $\mathrm{kHz}$ (standar asli) dan $134.5 \mathrm{kHz}$ (standar internasional). Arsitektur sistem RFID terdiri dari reader dan tag. Tag RFID berupa chip silikon yang mampu menyimpan data dan mengirimkannya melalui gelombang radio. Tag RFID dikenal sebagai transponder, yaitu kombinasi dari transmitter dan receiver yang didesain untuk menerima sinyal gelombang radio tertentu dan mengirimkan respon secara otomatis [9].
Berdasarkan sumber energi pada tag, tag RFID terbagi menjadi dua yaitu tag pasif dan tag aktif. Tag pasif merupakan tag yang tidak memiliki sumber energi internal, dan mampu mengirimkan data dengan memanfaatkan sumber tenaga medan elektomagnetis yang berasal dari reader. Pada tag pasif terdapat sirkuit resonan yang memiliki kemampuan meresap energi yang dihasilkan dari antena reader. Tag pasif memiliki sentuk yang lebih kecil dan praktis, tetapi jangkauan reader untuk mendeteksi menjadi lebih terbatas. Tag aktif merupakan tag yang memiliki sumber energi sendiri, biasanya berupa baterai internal. Tag aktif mampu dideteksi oleh reader dalam jarak yang jauh karena dapat mengirimkan sinyal secara aktif kepada reader, namun bentuk tag menjadi lebih besar karena sumber energi yang dimiliki [13].

\section{B. Sistem Kendali}

Sistem kendali adalah suatu sistem yang keluarannya dikendalikan pada suatu nilai tertentu atau untuk mengubah beberapa ketentuan yang telah ditetapkan oleh masukan ke sistem. Bentuk dasar sistem kendali dibagi menjadi dua yaitu sistem kendali kalangterbuka dan sistem kendali kalang-tertutup. Pada sistem kalang-terbuka, masukan sistem berbasis pengalaman untuk memberikan nilai keluaran yang diinginkan, dalam hal ini keluaran tidak dapat dimodifikasi untuk mengatasi perubahan kondisi. Sedangkan pada sistem kalang-tertutup sebuah isyarat dari keluaran diumpan-balikan ke masukan dan digunakan untuk mengubah masukan sehingga keluaran dipertahankan pada posisi ajeg dengan mengabaikan pada beberapa perubahan kondisi [12].

\section{Mikrokontroler}

1) Definisi dan Fungsi Mikrokontroler

Mikrokontroler adalah suatu unit mikroprosesor meliputi CPU, ROM, RAM, $\mathrm{I} / \mathrm{O}$, clock, dan peralatan lain yang saling 
ELECTRICIAN - Jurnal Rekayasa dan Teknologi Elektro

terhubung serta terorganisasi dalam melakukan pengendalian suatu sistem untuk tujuan tertentu [3].

\section{2) Mikrokontroler AVR}

Mikrokontroler AVR merupakan salah satu jenis mikrokontroler yang dibuat oleh Atmel Corp. Mikrokontroler ini berupa chip atau IC (Integrated Circuit) yang berisikan mikroprosesor, memori, modul-modul masukan keluaran yang dapat diprogram untuk melaksanakan fungsi tertentu sesuai dengan kebutuhan [14].

\section{3) Mikrokontroler Arduino}

Komponen utama Arduino ialah mikrokontroler AVR dari perusahaan Atmel. Arduino merupakan suatu platform elektronik berbasis pada perangkat lunak dan perangkat keras yang bersifat fleksibel sehingga mudah digunakan. Sistem Arduino sangat interaktif pada sistem masukan keluaran sederhana serta dapat menanggapi situasi dan kondisi di lingkungan sekitar yang nyata. Arduino tidak hanya untuk papan rangkaian elektroniknya saja, namun juga digunakan untuk bahasa pemrograman serta perangkat lunak pemrogramannya [2].

\section{Rele}

Rele merupakan komponen elektronik yang berfungsi sebagai saklar elektronis dan dapat dikendalikan dari rangkaian elektronik lainnya dengan arus listrik. Rele memiliki tiga bagian utama, yaitu koil, common, dan kontak. Pada prinsipnya Rele merupakan tuas saklar dengan lilitan kawat pada batang besi (solenoid) di dekatnya. Kontak saklar akan menutup bila solenoid dialiri oleh arus di mana tuas akan tertarik karena adanya gaya magnet yang terjadi pada solenoid. Kontak saklar akan kembali membuka saat tidak ada lagi arus yang mengaliri solenoid [10].

\section{E. LCD (Liquid Crystal Display)}

LCD (Liquid Crystal Display) merupakan perangkat elektronika yang telah terkonfigurasi dengan kristal cair dalam gelas plastik atau kaca sehingga mampu memberikan tampilan berupa titik, garis, simbol, huruf, angka ataupun gambar. LCD terbagi menjadi dua macam berdasarkan bentuk tampilannya, yaitu Text-LCD dan Graphic-LCD. Perbedaan kedua macam LCD tersebut ialah bentuk tampilan pada Text-LCD berupa huruf atau angka, sedangkan bentuk tampilan pada Graphic-LCD berupa titik, garis dan gambar [8].

Media penampil LCD telah banyak digunakan dalam alat-alat elektronik sederhana hingga alat-alat elektronik canggih seperti telepon genggam dan layar komputer. Media penampil yang biasa digunakan pada rangkaian elektronika sederhana ialah LCD $16 \times 2$, yakni LCD yang memiliki ukuran tampilan karakter sebesar 16 baris dan dua kolom [6].

\section{F. GPS ( Global Positioning System)}

Satelit merupakan stasiun komunikasi ruang angkasa yang mengorbit dengan periode revolusi dan rotasi tertentu. Stasiun ruang angkasa ini terdiri dari beberapa perangkat elektronik yang berfungsi sebagai repeater untuk menerima sinyal dari stasiun bumi kemudian memperkuat sinyal tersebut agar dapat dipancarkan kembali ke arah bumi sesuai dengan jarak jangkauan antara stasiun ruang angkasa dan lokasi stasiun bumi [5].

Satelit Navigasi adalah satelit yang berfungsi untuk menentukan lokasi sebuah titik di permukaan bumi dengan memanfaatkan sinyal radio sebagai media komunikasi antara stasiun ruang angkasa dan stasiun bumi. GPS merupakan sistem radio navigasi dan penentuan posisi menggunakan satelit. Sistem ini diciptakan untuk memberikan informasi posisi, kecepatan, dan waktu secara kontinu dan teliti dengan 
memanfaatkan satelit-satelit yang mengorbit [4].

\section{G. GSM (Global System for Mobile Communication)}

GSM adalah sistem komunikasi seluler generasi kedua yang menjadi standar global komunikasi nirkabel. Teknologi GSM merupakan standar komunikasi yang lebih banyak diterapkan pada telepon genggam yang digunakan sebagai alat komunikasi bergerak [7].

GSM merupakan standar komunikasi yang menyediakan layanan komunikasi dalam bentuk pesan pendek SMS (Short Message Service). Layanan komunikasi pertukaran pesan pendek antar pengguna jaringan GSM inilah yang paling banyak digunakan oleh masyarakat. Jangkauan frekuensi standar komunikasi GSM yakni 935-960 MHz untuk transmisi base dan $890-915 \mathrm{MHz}$ untuk transmisi bergerak [11].

\section{PERANCANGAN DESAIN}

\section{A. Perancangan Alat dan Sistem}

Pada tahapan ini dilakukan perancangan alat dan sistem secara keseluruhan yang membentuk sistem keamanan ganda interaktif pada kendaraan bermotor roda dua yang ingin diwujudkan, dapat dilihat pada diagram alir Gambar 1.

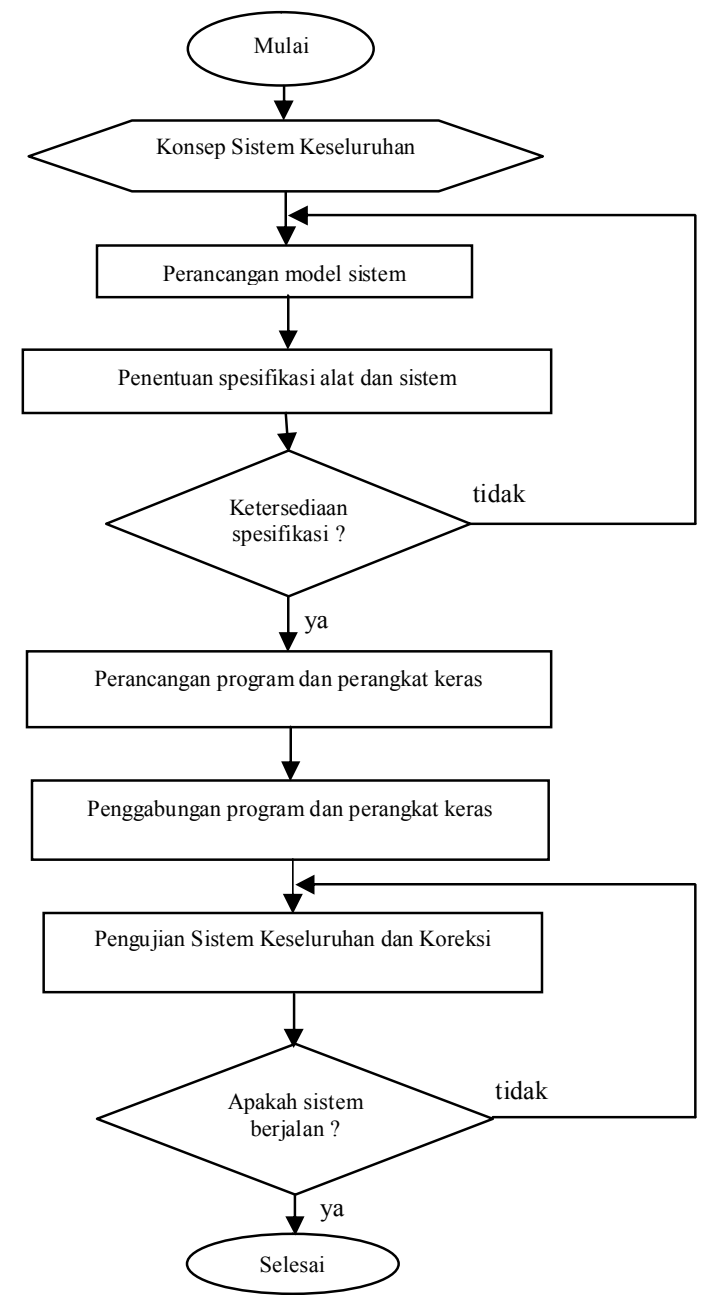

Gbr 1. Diagram alir perancangan alat dan sistem

Perancangan sistem keamanan ganda berbasis RFID ini akan diterapkan pada model kendaraan yang telah ditentukan, yaitu motor pabrikan Honda yang memiliki box penyimpanan dengan ukuran yang cukup besar.

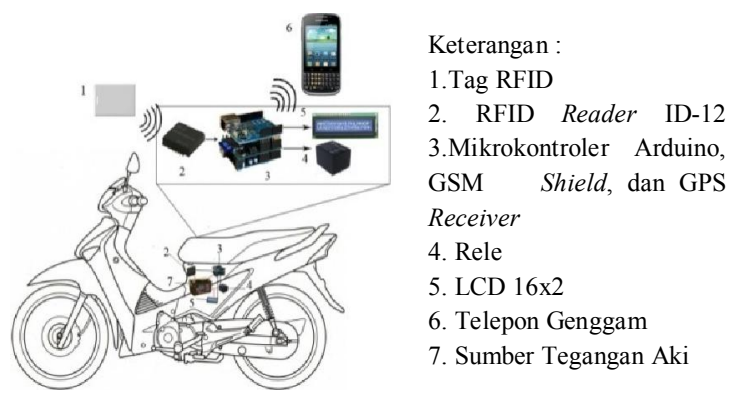

Gbr 2. Desain sistem keamanan ganda interkatif berbasis RFID 
Sistem keamanan ganda pada kendaraan bermotor roda dua berbasis RFID merupakan sistem kendali kalang-terbuka di mana sistem pengendaliannya mengacu pada hasil keluaran deteksi yang diberikan oleh sistem deteksi RFID dan tidak memiliki umpan balik yang dikirimkan kembali untuk proses koreksi. Berikut gambar diagram blok sistem secara keseluruhan:

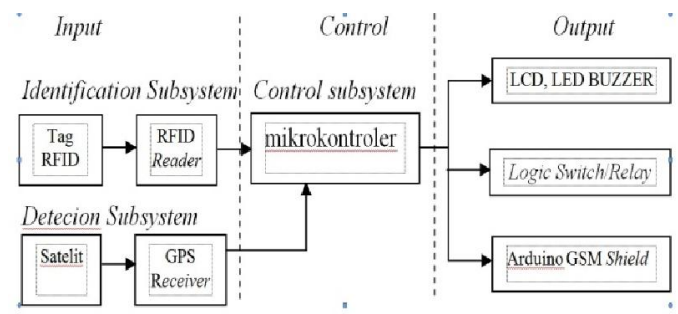

Gbr 3. Diagram blok sistem keseluruhan

Sistem keamanan ganda interaktif kendaraan bermotor roda dua berbasis RFID terdiri dari beberapa subsistem yaitu subsistem identifikasi, subsistem deteksi, subsistem pengendali, dan subsistem keluaran.

\section{1) Subsistem Identifikasi}

Subsistem ini melakukan identifikasi masukan. Subsistem deteksi RFID terdiri dari tag RFID, RFID Reader dan pengendali utama Mikrokontroler Arduino Uno R3.

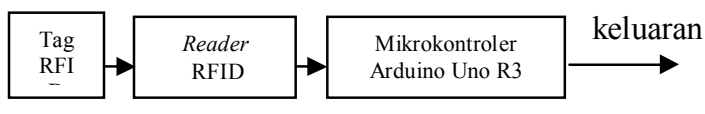

Gbr 4. Diagram blok subsistem identifikasi RFID

RFID Reader akan membaca identitas tag RFID, data informasi dari tag RFID akan dikirimkan ke Mikrokontroler Arduino Uno R3 sebagai pengendali.

\section{2) Subsistem Deteksi}

Subsistem deteksi GPS terdiri dari satelit, GPS Receiver dan pengendali utama Mikrokontroler Arduino Uno R3.

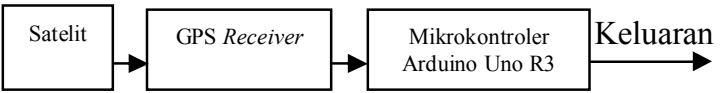

Gbr 5. Diagram blok subsistem deteksi gps

Satelit akan mendeteksi keberadaan GPS Receiver dan mengirimkan data dalam format NMEA dan GGA sebagai informasi. Data tersebut kemudian dikirimkan meuju Mikrokontroler Arduino Uno R3.

3) Subsistem Keluaran

Subsistem keluaran (Output System) terdiri dari subsistem Output Minimum, subsistem Aksi Rele dan subsistem Komunikasi GSM. Pada Subsistem Output Minimum terdapat LED dan Buzzer sebagai indikator yang menandai adanya masukan serta LCD 16x2 sebagai penampil data keluaran.

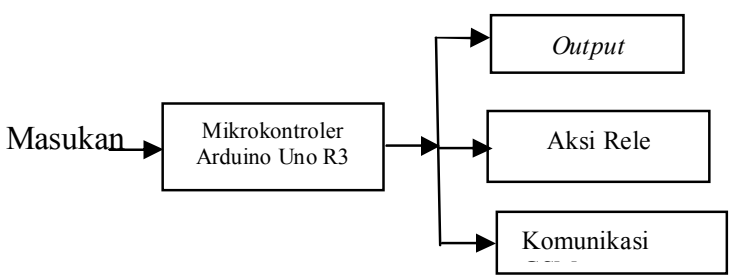

Gbr 6. Diagram blok subsistem keluaran

Subsistem Aksi, yakni subsistem yang berfungsi sebagai pemutus/penyambung rangkaian pengapian pada kendaraan bermotor roda dua. Hal itu terwujud dengan menggunakan komponen Rele sebagai saklar otomatis.

Mikrokontroler Arduino Uno mampu memberikan inisialisasi output 5 volt (kondisi high) sebagai trigger untuk mengaktifkan rele sehingga rangkaian sistem pengapian motor dapat tersambung. Rangkaian tersebut terhubung dengan saklar kunci kendaraaan, sehingga sistem pengapian kendaraan hanya akan aktif pada saat rele dan kunci kontak dalam keadaan terhubung

Subsistem komunikasi GSM berfungsi sebagai piranti yang mendukung komunikasi antara mikrokontroler dan telepon genggam pemilik kendaraan. Subsistem komunikasi 
terwujud dengan menggunakan modul Linksprite ATWIN GSM Shield yang kompatibel untuk mikrokontroler Arduino Uno R3. Modul GSM ini membutuhkan protokol ATcommand dalam pelaksanaan fungsinya, sehingga harus dideskripsikan dalam kode program mikrokontroler Arduino.

\section{B. Konsep Pengujian Alat dan Sistem}

Pengujian alat dan sistem dilakukan secara bertahap dari mulai pengujian tunggal fungsi komponen/alat, pengujian subsistem, dan pengujian sistem secara keseluruhan.

\section{1) Pengujian Tunggal Fungsi \\ Komponen/Alat}

Pengujian fungsi komponen/perangkat/ piranti dilakukan untuk menghindari terjadinya error atau galat yang diakibatkan tidak berfungsinya salah satu komponen/alat. Pengujian dilakukan dengan menggunakan alat ukur multimeter digital dan perangkat lunak untuk masing-masing piranti.

\section{2) Pengujian Subsistem}

Pengujian subsistem dilakukan untuk memastikan subsistem mampu melaksanakan fungsinya sesuai kebutuhan sistem. Pengujian dilakukan terhadap subsistem deteksi, subsistem kendali dan subsistem keluaran kemudian mengamati keluaran yang diberikan apakah sesuai dengan ketentuan atau tidak.

\section{3) Pengujian Sistem}

Pengujian dilakukan pada sistem secara menyeluruh dengan cara menggabungkan subsistem-subsistem menjadi satu kesatuan sistem, mengoperasikan sistem, menguji fungsi sistem, dan mengamati keluaran atau hasil operasi sistem.

\section{PENGUJIAN DAN PEMBAHASAN}

\section{A. Pengujian Fungsi Komponen/Perangkat/ Piranti}

1) Pengujian Sumber Tegangan

Pengujian sumber tegangan dilakukan untuk mengetahui kapasitas dari sumber tegangan apakah dapat memberikan tegangan yang dibutuhkan oleh sistem.

Sumber tegangan dihubungkan dengan rangkaian regulator yang terdiri dari beberapa komponen IC regulator tegangan 7805, 7809, dan 7812. Hal tersebut dilakukan untuk menyesuaikan berbagai kebutuhan tegangan pada sistem.

Tabel 1. Hasil Pengujian Sumber Tegangan

\begin{tabular}{|c|c|c|c|c|c|}
\hline Pengujian & $\begin{array}{c}\text { Sumber } \\
\text { Teganga } \\
\text { n Ideal } \\
\text { (Volt) }\end{array}$ & $\begin{array}{c}\text { Sumber } \\
\text { Tegangan } \\
\text { Terukur } \\
\text { (Volt) }\end{array}$ & $\begin{array}{c}\text { IC Regu } \\
\text { lator } \\
7805 \\
\text { (Volt) }\end{array}$ & $\begin{array}{c}\text { IC Regu } \\
\text { lator } \\
7809 \\
\text { (Volt) }\end{array}$ & $\begin{array}{c}\text { IC Regu } \\
\text { lator } \\
\text { (Volt) }\end{array}$ \\
\hline 1 & 12 & 12.47 & 4.99 & 8.97 & 11.55 \\
\hline 2 & 12 & 12.45 & 4.99 & 8.97 & 11.55 \\
\hline 3 & 12 & 12.52 & 4.99 & 8.97 & 11.55 \\
\hline 4 & 12 & 12.53 & 4.99 & 8.97 & 11.55 \\
\hline 5 & 12 & 12.50 & 4.99 & 8.97 & 11.55 \\
\hline 6 & 12 & 12.48 & 4.99 & 8.97 & 11.55 \\
\hline 7 & 12 & 12.47 & 4.99 & 8.97 & 11.55 \\
\hline 8 & 12 & 12.47 & 4.99 & 8.97 & 11.55 \\
\hline 9 & 12 & 12.52 & 4.99 & 8.97 & 11.55 \\
\hline 10 & 12 & 12.47 & 4.99 & 8.97 & 11.55 \\
\hline Rata-rata & 12 & 12.488 & 4.99 & 8.97 & 11.55 \\
\hline
\end{tabular}

Dari hasil pengujian sumber tegangan dapat diperoleh nilai galat terhitung sebagai berikut:

Galat $=\mid$ Nilai Tegangan Ideal - Nilai

Tegangan Terukur Rata-rata|

$$
\begin{aligned}
& \text { Galat }=|12-12.488| \\
& \begin{aligned}
\text { Galat }=|-0.488| & =0.488 \\
\text { Persentase Galat } & =\frac{0.488}{12} \times 100 \% \\
= & 4.067 \%
\end{aligned}
\end{aligned}
$$


2) Pengujian Tag dan Reader RFID

Pada pengujian ini digunakan tiga unit tag RFID. Pengujian dilakukan dengan menggunakan perangkat lunak RFID Tester. Rangkaian minimum RFID akan terhubung dengan satu unit komputer portabel penelitian ACER 4752G. Rangkaian minimum RFID akan mengirimkan data yang terdapat pada tag RFID secara serial ke unit komputer melalui kabel USB to Serial RS232.

Pada pengujian tag RFID pertama didapatkan data dengan nomor kartu 8803460 (tag 1). Pada pengujian tag RFID kedua didapatkan data dengan nomor kartu 8803459 (tag 2). Pada pengujian tag RFID ketiga didapatkan data dengan nomor kartu 7206252 (tag 3).

3) Pengujian Mikrokontroler Arduino Uno R3

Pengujian pengendali utama Mikrokontroler Arduino Uno R3 bertujuan untuk mengetahui kondisi Mikrokontroler Arduino Uno R3 dalam kondisi baik atau tidak. Pengujian pengendali utama Mikrokontroler Arduino Uno R3 dilakukan dengan menggunakan perangkat lunak IDE (Integrated Development Environment) Arduino 1.0.5. Kondisi Mikrokontroler Arduino dapat diketahui dengan cara menghubungkannya dengan komputer dan mengunggah program contoh ke Arduino Uno R3 dengan perangkat lunak IDE Arduino tersebut.

\section{B. Pengujian Subsistem}

1) Pengujian Subsistem Identifikasi RFID

Pada pengujian subsistem digunakan sebuah unit RFID Reader ID-12 LA, satu unit Mikrokontroler Arduino Uno R3, satu rangkaian sistem minimum output, dan perangkat lunak IDE Arduino 1.0.5. Pengujian ini dilakukan untuk mengertahui kemampuan RFID Reader dalam membaca Tag RFID yang kemudian mengirimkan informasi data ASCII kepada Mikrokontroler Arduino Uno R3 dan ditampilkan pada serial monitor perangkat lunak IDE Arduino 1.0.5.

Tabel 2. Hasil Pengujian Subsistem Identifikasi RFID

\begin{tabular}{|c|c|c|}
\hline No & Tag & Data \\
\hline 1 & Tag 1 & 2C006DF56CD8 \\
\hline 2 & Tag 2 & 6 F008654833E \\
\hline 3 & Tag 3 & 6 F0086548439 \\
\hline
\end{tabular}

2) Pengujian Subsistem Deteksi GPS

Pada pengujian digunakan sebuah unit GPS Receiver U-blox CN-06, satu unit Mikrokontroler Arduino Uno R3, perangkat lunak IDE Arduino 1.0.5, perangkat komputer, dan perangkat lunak U-Center GPS Evaluation Software. Pengambilan data GPS (Global Positioning System) berupa data latitude dan longitude dilaksanakan pada beberapa titik di daerah Universitas Lampung dan di luar Universitas Lampung secara acak. Hasil Pengujian Subsistem Deteksi GPS dapat dilihat pada Tabel 3.

Tabel 3. Hasil Pengujian Subsistem Deteksi Gps

\begin{tabular}{|c|c|c|c|c|c|}
\hline \multirow{2}{*}{ NO } & \multirow{2}{*}{ LOKASI } & \multicolumn{2}{|c|}{ DATA LATITUDE } & \multicolumn{2}{c|}{ DATA LONGITUDE } \\
\cline { 3 - 6 } & & $\operatorname{Min}\left({ }^{\circ}\right)$ & $\operatorname{Max}\left({ }^{\circ}\right)$ & $\operatorname{Min}\left({ }^{\circ}\right)$ & $\operatorname{Max}\left({ }^{\circ}\right)$ \\
\hline 1 & $\begin{array}{c}\text { Kediaman } \\
\text { Pribadi }\end{array}$ & -5.354103 & -5.353969 & 105.242367 & 105.242538 \\
\hline \multirow{2}{*}{2} & $\begin{array}{c}\text { Lab. Terpadu } \\
\text { Teknik elektro }\end{array}$ & -5.361832 & -5.361048 & 105.242100 & 105.242880 \\
\hline 3 & $\begin{array}{c}\text { Perpustakaan } \\
\text { UNILA }\end{array}$ & -5.362279 & -5.361438 & 105.239828 & 105.240764 \\
\hline 4 & $\begin{array}{c}\text { Dekanat FT } \\
\text { UNILA }\end{array}$ & -5.363354 & -5.362699 & 105.242475 & 105.243048 \\
\hline 5 & $\begin{array}{c}\text { REKTORAT } \\
\text { UNILA }\end{array}$ & -5.364823 & -5.364115 & 105.242715 & 105.243357 \\
\hline
\end{tabular}

3) Pengujian Subsistem Aksi Rele

Pada pengujian digunakan sumber tegangan 12 volt, rangkaian Penggerak Rele, satu unit Mikrokontroler Arduino Uno R3, perangkat komputer, dan perangkat lunak IDE Arduino 1.0.5.

Pengujian dilakukan untuk mengetahui kinerja rangkaian Penggerak Rele sebagai saklar penyambung dan pemutus berdasarkan perintah yang diberikan oleh pengendali utama Mikrokontroler Arduino Uno R3. Perintah tersebut dipengaruhi oleh karakter 
masukan yang diterima dari perangkat komputer melalui komunikasi serial dengan media kabel USB. Karakter "1" menjadikan Rele ke posisi tersambung sehingga LED menyala, sedangkan karakter " 0 " menjadikan Rele kembali ke posisi terputus sehingga LED tidak menyala. Hasil pengujian subsistem aksi Rele tersaji di dalam tabel berikut ini:

Tabel 4. Hasil Pengujian Subsistem Aksi Rele

\begin{tabular}{|c|c|c|c|c|c|}
\hline $\begin{array}{c}\mathrm{N} \\
\mathrm{o}\end{array}$ & $\begin{array}{c}\text { Karak } \\
\text { ter }\end{array}$ & $\begin{array}{c}\text { Aksi Mikro } \\
\text { kontroler }\end{array}$ & $\begin{array}{c}\text { Kondisi } \\
\text { Rele }\end{array}$ & $\begin{array}{c}\text { Input } \\
\text { Sak lar }\end{array}$ & $\begin{array}{c}\text { Kondisi LED } \\
\text { Indikator }\end{array}$ \\
\hline 1 & 0 & LOW & Terputus & Off & Tidak Hidup \\
\hline 2 & 1 & HIGH & $\begin{array}{c}\text { Terhubu } \\
\text { ng }\end{array}$ & Off & Tidak Hidup \\
\hline 3 & 0 & LOW & Terputus & On & Tidak Hidup \\
\hline 4 & 1 & HIGH & $\begin{array}{c}\text { Terhubu } \\
\text { ng }\end{array}$ & On & Hidup \\
\hline
\end{tabular}

\section{4) Pengujian Subsistem Komunikasi GSM}

Pada pengujian digunakan satu unit Mikrokontroler Arduino Uno R3, modul Linksprite ATWIN Quadband GPRS/GSM Shield, satu telepon genggam, perangkat komputer, perangkat lunak IDE Arduino 1.0.5, dan perangkat lunak SSCOM32E. Pengujian dilakukan untuk memastikan modul Linksprite ATWIN Quadband GPRS/GSM Shield mampu mewujudkan komunikasi antara Mikrokontroler arduino dengan telepon genggam.

Linksprite ATWIN Quadband GPRS/GSM Shield merupakan modul komunikasi yang kompatibel untuk Mikrokontroler Arduino Uno R3. Modul komunikasi ini mendukung layanan GSM. Linksprite Quadband GPRS/GSM Shield mendukung fitur SMS (Short Message Service) dalam format Teks dan PDU (biner). Linksprite ATWIN Quadband GPRS/GSM Shield memiliki frekuensi kerja sebesar 900 $\mathrm{MHz}$ yang sangat mendukung untuk digunakan di Indonesia.

Tabel 5. Hasil Pengujian Komunikasi Gsm

\begin{tabular}{|c|c|c|c|}
\hline No & Karakter & Aksi Mikrokontroler & Aksi GSM \\
\hline 1 & $\mathrm{~s}$ & AT $+\mathrm{CMGS}=\backslash "+6285267897892 \backslash "$ & Mengirim SMS \\
\hline 2 & $\mathrm{t}$ & ATD $+6285267897892 ;$ & Menelpon \\
\hline
\end{tabular}

\section{Pengujian Sistem}

Pengujian sistem merupakan pengujian yang dilakukan setelah mengintegrasikan subsistem-subsistem yang ada menjadi satu.

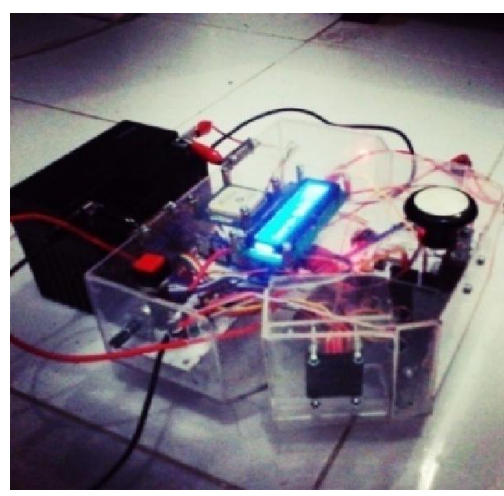

Gbr 7. Realisasi sistem

Pada pengujian ini dilakukan penghitungan waktu tunda yang terjadi pada sistem, dapat diketahui bahwa terdapat waktu tunda untuk beberapa aksi yang diberikan sebagai wujud respon terhadap beberapa kondisi yang menjadi masukan sistem dan tertera pada tabel berikut ini:

Tabel 6. Waktu Tunda Sistem

\begin{tabular}{|c|c|c|c|c|}
\hline Penguji an & $\begin{array}{c}\text { Waktu } \\
\text { Tunda } \\
\text { Persiapan } \\
\text { (detik) }\end{array}$ & $\begin{array}{c}\text { Waktu } \\
\text { Tunda } \\
\text { Kerja } \\
\text { Rele On } \\
\text { (detik) }\end{array}$ & $\begin{array}{c}\text { Waktu } \\
\text { Tunda } \\
\text { Kerja Rele } \\
\text { Off- } \\
\text { 1(detik) }\end{array}$ & $\begin{array}{c}\text { Waktu } \\
\text { Tunda } \\
\text { Kerja Rele } \\
\text { Off- } \\
\text { 2(detik) }\end{array}$ \\
\hline 1 & 5 & 0 & 1 & 1 \\
\hline 2 & 6 & 0 & 1 & 1 \\
\hline 3 & 5 & 0 & 2 & 1 \\
\hline 4 & 6 & 0 & 1 & 1 \\
\hline 5 & 7 & 0 & 2 & 1 \\
\hline 6 & 4 & 0 & 2 & 1 \\
\hline 7 & 5 & 0 & 1 & 1 \\
\hline 8 & 5 & 0 & 3 & 1 \\
\hline 9 & 8 & 0 & 2 & 1 \\
\hline 10 & 5 & 0 & 1.6 & 1 \\
\hline Rata-rata & 5.6 & 0 & & \\
\hline
\end{tabular}

Waktu tunda persiapan merupakan waktu tunda yang terjadi saat sistem baru dihidupkan. Waktu tunda kerja Rele On adalah waktu tunda yang dibutuhkan setelah kondisi masukan tag RFID benar dan Kontak kendaraan $O n$ hingga Rele menjadi aktif. Waktu tunda kerja Rele Off 1 adalah waktu 
tunda yang dibutuhkan setelah kondisi Kontak kendaraan Off hingga Rele menjadi tidak aktif. Waktu tunda kerja Rele Off 2 adalah waktu tunda yang dibutuhkan setelah kondisi masukan karakter GSM terpenuhi hingga Rele menjadi tidak aktif. Sistem mengalami waktu tunda persiapan rata-rata sebesar 5.6 detik setelah mendapatkan daya dari sumber tegangan. Sistem mampu memberikan aksi terhadap kondisi masukan yang terjadi dengan waktu tunda kerja ratarata sebesar 1.6 detik.

Hasil pengujian sistem tersaji dalam tabel berikut ini:

Tabel 7. Hasil Pengujian Sistem

\begin{tabular}{|c|c|c|c|c|c|}
\hline $\begin{array}{l}\mathrm{N} \\
\mathrm{o}\end{array}$ & Masukan & $\begin{array}{l}\text { Input } \\
\text { Media }\end{array}$ & $\begin{array}{c}\text { Pengolah } \\
\text { Data }\end{array}$ & $\begin{array}{l}\text { Output } \\
\text { Media }\end{array}$ & Keluaran \\
\hline 1 & $\begin{array}{c}\text { Data } \\
\text { ASCII } \\
\text { Terdaftar }\end{array}$ & $\begin{array}{c}\text { Subsiste } \\
\mathrm{m} \\
\text { RFID }\end{array}$ & $\begin{array}{c}\text { Mikroko } \\
\text { ntroler } \\
\text { Arduino } \\
\text { Uno R3 }\end{array}$ & $\begin{array}{c}\text { Subsiste } \\
\text { m } \\
\text { Aksi } \\
\text { Rele }\end{array}$ & Rele Terhubung \\
\hline 2 & $\begin{array}{l}\text { Data } \\
\text { ASCII } \\
\text { Sesuai } \\
\text { dan } \\
\text { Kontak } \\
\text { On }\end{array}$ & $\begin{array}{c}\text { Subsiste } \\
\mathrm{m} \\
\text { RFID } \\
\text { dan Aksi } \\
\text { Rele }\end{array}$ & $\begin{array}{c}\text { Mikroko } \\
\text { ntroler } \\
\text { Arduino } \\
\text { Uno R3 }\end{array}$ & $\begin{array}{c}\text { Subsiste } \\
\text { m Aksi } \\
\text { Rele dan } \\
\text { Komuni } \\
\text { kasi } \\
\text { GSM }\end{array}$ & $\begin{array}{c}\text { Rangkaian } \\
\text { Mesin } \\
\text { Kendaraan } \\
\text { Terhubung dan } \\
\text { Panggilan } \\
\text { Telepon ke } \\
\text { Nomor Terdaftar }\end{array}$ \\
\hline 3 & $\begin{array}{l}\text { Data } \\
\text { GPS }\end{array}$ & $\begin{array}{c}\text { Subsiste } \\
\text { m } \\
\text { Deteksi } \\
\text { GPS }\end{array}$ & $\begin{array}{c}\text { Mikroko } \\
\text { ntroler } \\
\text { Arduino } \\
\text { Uno R3 }\end{array}$ & $\begin{array}{c}\text { Subsiste } \\
\text { m } \\
\text { Minimu } \\
\text { m } \\
\text { Output }\end{array}$ & $\begin{array}{l}\text { Tampilan } \\
\text { Data } \\
\text { LCD } 16 \times 2\end{array}$ \\
\hline 4 & $\begin{array}{c}\text { Saklar } \\
\text { Kontak } \\
\text { Kendaraa } \\
\text { n }\end{array}$ & $\begin{array}{c}\text { Subsiste } \\
\text { m } \\
\text { Aksi } \\
\text { Rele }\end{array}$ & $\begin{array}{c}\text { Mikroko } \\
\text { ntroler } \\
\text { Arduino } \\
\text { Uno R3 }\end{array}$ & $\begin{array}{c}\text { Subsiste } \\
\text { m Aksi } \\
\text { Rele dan } \\
\text { Komuni } \\
\text { kasi } \\
\text { GSM }\end{array}$ & $\begin{array}{c}\text { Rangkaian Mesin } \\
\text { Kendaraan } \\
\text { Terputus Dan } \\
\text { SMS } \\
\text { Keluar Informasi } \\
\text { Posisi Kendaraan }\end{array}$ \\
\hline 5 & $\begin{array}{c}S M S \\
\text { masuk } \\
\text { "\#ao" }\end{array}$ & $\begin{array}{c}\text { Subsiste } \\
\text { m } \\
\text { GSM }\end{array}$ & $\begin{array}{c}\text { Mikroko } \\
\text { ntroler } \\
\text { Arduino } \\
\text { Uno R3 }\end{array}$ & $\begin{array}{c}\text { Subsiste } \\
\text { m Aksi } \\
\text { Rele dan } \\
\text { Komuni } \\
\text { kasi } \\
\text { GSM }\end{array}$ & $\begin{array}{c}\text { Rangkaian Mesin } \\
\text { Kendaraan } \\
\text { Terputus Dan } \\
\text { SMS } \\
\text { Keluar Informasi } \\
\text { Posisi Kendaraan }\end{array}$ \\
\hline 6 & $\begin{array}{c}\text { Panggilan } \\
\text { Masuk } \\
\text { Nomor } \\
\text { Terdaftar }\end{array}$ & $\begin{array}{c}\text { Sub } \\
\text { sistem } \\
\text { GSM }\end{array}$ & $\begin{array}{c}\text { Mikroko } \\
\text { ntroler } \\
\text { Arduino } \\
\text { Uno R3 }\end{array}$ & $\begin{array}{c}\text { Subsiste } \\
\text { m Aksi } \\
\text { Rele dan } \\
\text { Komuni } \\
\text { kasi } \\
\text { GSM }\end{array}$ & $\begin{array}{c}\text { Rangkaian Mesin } \\
\text { Kendaraan } \\
\text { Terputus Dan } \\
\text { SMS } \\
\text { Keluar Informasi } \\
\text { Posisi Kendaraan }\end{array}$ \\
\hline
\end{tabular}

Tabel 7 menunjukkan berbagai kondisi masukan serta bentuk aksi yang diberikan oleh sistem. Mikrokontroler Arduino Uno R3 memberikan aksi dengan menghubungkan Relay apabila data tag RFID sesuai. Aksi berikutnya adalah melakukan panggilan telepon ke nomor telepon terdaftar apabila data tag RFID sesuai dan kondisi kunci kontak kendaraan dalam kondisi On. Aksi sistem lainnya adalah mengirimkan informasi letak posisi kendaraan dalam bentuk pesan pendek ke nomor telepon terdaftar seperti pada Gambar 8.

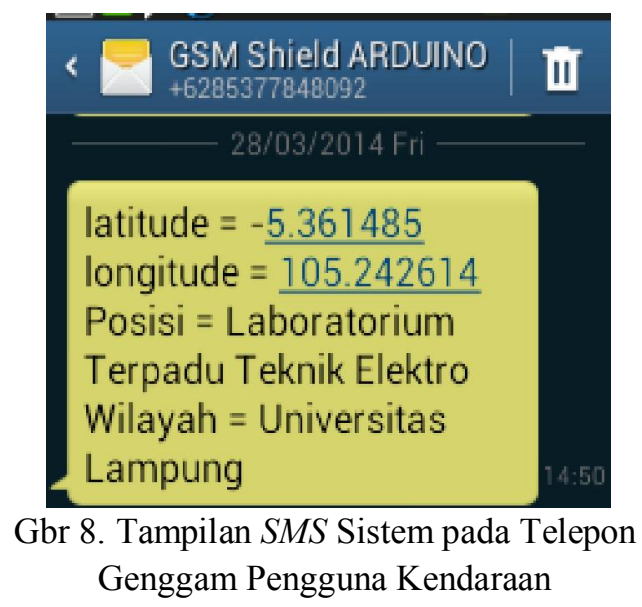

\section{Pembahasan}

Berdasarkan hasil pengujian-pengujian yang telah dilaksanakan pada sistem untuk proses kerja identifikasi, deteksi, aksi dan komunikasi diperoleh hasil yang sesuai dengan ketentuan fungsi sistem. Sistem mampu membedakan objek tag RFID sebagai kunci akses mesin kendaraan dari data ASCII yang tersimpan di dalam tag RFID kemudian melakukan aksi dengan menghubungkan rangkaian mesin kendaraan, sistem mampu membedakan karakter SMS masuk melalui modul Linksprite GSM Shield sebagai masukan karakter kemudian melakukan aksi dengan membalas $S M S$ yang berisi informasi posisi kendaraan sehingga sistem ini mampu berkomunikasi dengan perangkat telepon genggam pemilik kendaraan.

Proses kerja identifikasi, deteksi, dan komunikasi pada sistem membutuhkan proses komunikasi serial dengan pengolah data utama Mikrokontroler Arduino Uno R3. Pengolah data utama Mikrokontroler Arduino Uno R3 hanya memiliki sepasang pin komunikasi serial penerima data $(\mathrm{Rx})$ dan 
pengirim data $(\mathrm{Tx})$, di mana sepasang pin komunikasi serial hanya mampu berkomunikasi dengan satu proses penerimaan data dalam satu waktu. Hal ini menyebabkan kebutuhan sistem yang memiliki tiga proses komunikasi serial (identifikasi RFID, deteksi GPS, dan komunikasi GSM) belum terpenuhi bila hanya memanfaatkan sepasang pin komunikasi serial tersebut. Kebutuhan tersebut dipenuhi dengan menggunakan dua pasang pin fake serial tambahan dengan memanfaatkan librari kode program "SoftwareSerial" dan "AltSoftSerial". Pin komunikasi serial tersebut bekerja pada Baud Rate yang sama yaitu 9600. Pada dasarnya pin fake serial memiliki prinsip kerja yang sama seperti pin serial asli yang terdapat pada Arduino Uno R3, namun pin-pin tesebut bekerja bergantian dalam waktu yang sangat singkat dengan resiko waktu tunda (delay) yang terakumulasi.

Dari hasil pengujian dapat diketahui bahwa terdapat waktu tunda kerja yang dialami oleh sistem. Waktu tunda disebabkan oleh beberapa faktor, antara lain pengaruh kondisi lingkungan berupa konstruksi bangunan serta cuaca lingkungan yang mampu mengganggu keadaan sinyal untuk komunikasi data dan pengaruh waktu tunda program. Kinerja dari GPS Receiver untuk menerima data dari satelit dan mengirimkannya ke Mikrokontroler Arduino Uno R3 sangat terpengaruh oleh konstruksi bangunan yang menghalangi transmisi gelombang radio antara GPS Receiver dan satelit-satelit. Hal tersebut juga mempengaruhi kinerja dari GSM Shield untuk menerima data berupa pesan pendek atau panggilan saat kehilangan sinyal. Waktu tunda pada program yang diunggah pada Mikrokontroler Arduino Uno R3 merupakan waktu tunda utama dari nilai waktu tunda kerja sistem.

\section{KESIMPULAN}

Berdasarkan hasil pengujian dan pembahasan, maka dapat disimpulkan bahwa telah terwujud sebuah sistem keamanan ganda interaktif pada kendaraan bermotor roda dua yang mampu membedakan tag RFID berdasarkan data ASCII yang tersimpan untuk menghidupkan kendaraan serta mampu memberikan informasi keberadaan kendaraan. Sistem keamanan tersebut dilengkapi sebuah fitur keamanan darurat dengan memanfaatkan komunikasi GSM untuk menghentikan kendaraan dalam situasi kendaraan telah dicuri. Akurasi informasi dipengaruhi oleh kondisi lingkungan serta waktu tunda kerja sistem. Waktu tunda keseluruhan sistem masih dapat ditoleransi untuk efektifitas kerja sistem dengan nilai rata-rata waktu tunda persiapan 5.6 detik dan rata-rata waktu tunda kerja 1.6 detik. Perolehan galat sebesar 4.067 $\%$ pada sumber tegangan sistem menujukkan sumber tegangan sistem dalam kondisi yang baik.

\section{REFERENSI}

[1] (2013) RFID. Available: http://id.wikipedia.org/wiki/RFID

[2] Artanto, D, Interaksi Arduino dan LabView. PT Elex Media Komputindo, Jakarta, 2012.

[3] Budiharto dan Firmansyah, Elektonika Digital dan Mikroprosesor, CV. Andi Offset. Yogyakarta, 2010.

[4] Daryanto, Teknik Dasar Elektronika Komunikasi, Sarana Tutorial Nurani Sejahtera. Bandung, 2012.

[5] Gordon dan Morgan, Principles of Communication Satellites, John Wiley \& Sons, Inc, New York, 1993.

[6] Kadir, A, Pendidikan Praktis Mempelajari Aplikasi Mikrokontroler dan Pemrogramannya Menggunakan Arduino, Andi Offset. Yogyakarta, 2013.

[7] Le Bodic, Mobile Messaging Technologies and Services: SMS, EMS, and MMS. John Wiley \& Sons, Inc, Ontario, 2002. 
[8] Nurcahyo, S, Aplikasi dan Teknik Pemrograman Mikrokontroler AVR Atmel, CV Andi Offset, Yogyakarta, 2012.

[9] Polniak, S, The RFID Case Study Book. (RFID Application Stories from Around the Globe). Abisam Software, 2007.

[10] Prihono, Jago Elektronika Secara Otodidak, PT Kawan Pustaka, Jakarta, 2009.

[11] Stallings, Komunikasi \& Jaringan Nirkabel. Alih Bahasa oleh Dimas Aryo Pamungkas, S.T. Erlangga, Jakarta, 2007.

[12] Sulistiyanti, S.R., dkk, Dasar Sistem Kendali, Universitas Lampung. Bandarlampung, 2006.

[13] Thornton, F, et all, RFID Security, Syngress Publishing, Rockland. 2006.

[14] Winoto, A, Mikrokontroler AVR dan ATmega8/16/32/8535 dan Pemrogramannya dengan Bahasa C pada winAVR, Informatika Bandung, Bandung, 2008. 